\title{
Analysis Methods for Development of Certified Reference Material (CRM) Zircon Minerals Synthesis
}

\author{
Samin ${ }^{*}$ and Susanna Tuning Sunanti \\ ${ }^{1}$ Department of Process Technology, Center for Accelerator Science and Technology BATAN, \\ Jl.Babarsari, Kotak Pos 6101 ykbb, Yogyakarta 55281, Indonesia \\ Received May 22, 2017; Accepted February 13, 2018
}

\begin{abstract}
The synthesis method of in-house zircon minerals certified reference material (CRM) from Kalimantan (Tumbang Titi), and Bangka has been studied with statistical method of ISO 13528-2008 and ISO 35-2006. Zircon Minerals weighing of $10 \mathrm{~kg}$, and it was dried at $90{ }^{\circ} \mathrm{C}$ for $2 \times 6 \mathrm{~h}$ in a closed room, then crushed with a Ball-Mill up to passes 200 mesh, and homogenized in a homogenizer for $3 \times 6 \mathrm{~h}$. The water content in zircon minerals powder is tested by gravimetric method, whereas the homogeneity and stability assessed by statistical methods. Zircon mineral powders are distributed to seven accredited testing laboratory for testing the composition and content of the oxides with the validated analytical methods. Standardization and characterization of candidate zircon mineral certified reference materials are done by using XRD (X-Ray Diffraction) and used standard materials of JCRM R 502 from Japan. The test results of oxide concentrations from various laboratories processed with statistical methods. From the data by test laboratories obtained 40 bottles of the prototype in-house certified reference materials zircon mineral powders from Kalimantan and Bangka with a capacity of $100 \mathrm{~g}$. Based on standardization and characterization test data obtained a major chemical compound on zircon minerals Kalimantan and Bangka similar to the standard that is $\mathrm{ZrSiO}_{4}$. This in-house CRM is traced to certified reference materials from Japan (JCRM-502).
\end{abstract}

Keywords: in-house CRM; zirconium minerals; reference materials

\section{ABSTRAK}

Telah dilakukan pengembangan pembuatan bahan acuan standar bersertifikat (CRM) mineral zirkon dari Kalimantan (Tumbang Titi) dan Bangka dengan metode statistik ISO 13528-2008 dan ISO 35-2006. Mineral zirkon seberat $10 \mathrm{~kg}$, dikeringkan pada suhu $90{ }^{\circ} \mathrm{C}$ selama $2 \times 6$ jam di ruang tertutup, kemudian ditumbuk dengan alat Ball-Mill hingga lolos 200 mesh, dan dihomogenkan dalam alat homogenizer selama $3 \times 6$ jam. Kandungan air mineral zirkon diuji dengan metode gravimetri, sedangkan homogenitas dan stabilitas diuji dengan metode statistik ISO 13528-2008. Mineral zirkon serbuk didistribusikan ke 9 laboratorium pengujian terakreditasi untuk menguji komposisi dan kadar oksida dengan metode analisis yang divalidasi. Standardisasi dan karakterisasi kandidat bahan acuan standar mineral zirkon dilakukan dengan menggunakan XRD (X-Ray Diffraction) dan digunakan bahan standar primer JCRM R 502 buatan Jepang. Hasil tes kadar oksida dari berbagai laboratorium diolah dengan metode statistik. Dari data uji berbagai laboratorium diperoleh prototip serbuk bahan acuan standar bersertifikat inhouse mineral zirkon Kalimantan dan Bangka masing-masing sejumlah 40 botol, dengan kapasitas masing-masing $100 \mathrm{~g}$. Berdasarkan data uji standardisasi dan karakterisasi diperoleh senyawa kimia yang major pada mineral zirkon Kalimantan dan Bangka mirip sama dengan standarnya yaitu $\mathrm{ZrSiO}_{4}$. CRM in house ini tertelusur ke bahan acuan bersertifikat dari Jepang (JCRM-502).

Kata Kunci: CRM in-house; mineral zirkonium; bahan acuan

\section{INTRODUCTION}

Standardization of the analytical methodology and development of a quality control system in a laboratory can help ensure analytical measurement validity and increase data quality and reliability. Reference materials play key roles in the development of the internal quality control system [1]. Certified Reference Material (CRM) is a reference material characterized by a metrologically

* Corresponding author. Tel : +62-8156882743

Email address : samin@batan.go.id valid procedure for one or more specified properties, accompanied by a certificate that provides the value of the specified property, its associated uncertainty, and a statement of metrological traceability [2]. According to International Vocabulary of Metrology Basic and general concept and associated term (VIM): Reference Materials (RM) is material or substance one or more of its value sufficiently homogeneous and well established [3]. Certified reference materials (CRM) are essential 
for calibration, method validation, and quality control of analytical methods [4-5].

The international free market requires assurance and quality assurance of products traded [7]. It requires a definite standard, the infrastructure supporting the implementation of standards that are reliable and effective quality control [8]. From a testing laboratory is needed most the validity product test data. The application of laboratory accreditation system and application quality assurance test results is a key element to ensure the validity of test results $[1,7]$. CRM/SRM useful for calibration of measurement tools, validation of analytical methods, assign a value to a comparison [8-9]. Secondary reference materials, reference materials work, reference materials in-house, to ensure the traceability of test results, to check laboratory performance. The result of the analysis is an estimate of the true value. Forecast value has a range of value due to the measurement uncertainty: $x \pm u$. The uncertainty values describe the quality of the results [2]. The key element of the validity of the test results lies in traceability to a recognized reference point, namely the International System of Units or CRM [1,5,7]. CRM is capable of ensuring metrological traceability of measurement results to the International System of Units (SI), which corresponds to an "unbroken chain of calibrations, each contributing to the measurement uncertainty" $[5,7]$.

The purpose of this study is to obtain the current method of zircon mineral CRM synthesis and to get zircon mineral CRM which can be used for testing the quality of the mining material minerals.

Some of the techniques used for Reference Material certification covers measurement by the primary method in one organization, measurement by two or more independent reference methods in one organization, measurement by a network of competent laboratories using one or more different methods that have been proven to be accurate and measurement by a specific method in an interlaboratory comparison [4-7]. In the standard ISO/IEC 17025:2005 key principal quality assurance testing results is the use of reference materials and proficiency testing [2]. The laboratory was accredited under ISO/IEC 17025:2005 is required to use reference materials in the field of testing is concerned [9]. So the reference material is also one of the requirements for standardization, particularly in a system of laboratory accreditation and certification of products [2,10]. All SRM (Standard Reference Materials) accompanied by a certificate, so classified CRM. Certification CRM uses several main ways, is the primary method of measurement, measurement by testing interlaboratory comparisons using different methods, gravimetric measurements were checked value by other methods [11].
This research is still new and has never been done before by other researchers. There are several studies on the production and use of in-house CRM, among others Ahadnejad et al. from Iran [11], which has been researching on setting in-house XRF reference material for minerals, Jedziniak et al. [12] from Poland who has been researching on in-house reference materials 5-hydroxyflunixin and meloxicam in cow milk preparation and evaluation.

The certification of reference material is carried out according to the requirements of ISO Guide 352006. The ISO Guide 35 states that certification process of a candidate CRM requires a careful study of all sources of uncertainty that may cause an impact on the validity of certified values [2]. In general, the important uncertainty sources are characterization, homogeneity, transport and storage stability. These sources come from essential studies to the development and certification of CRM [2]. The characterization study determines the property values as part of the certification process. Homogeneity study is necessary for certification projects to demonstrate that the batch of bottles (units) is sufficiently homogeneous [2]. In the previous studies, for the certification of zircon mineral CRM materials candidate carried out by ISO $35-2006[2,10,16]$, whereas in this study to test the homogeneity and stability of the zircon mineral CRM candidate made by ISO 13528-2008 [1415].

\section{EXPERIMENTAL SECTION}

\section{Materials}

Zirconium Mineral from Kalimantan and Bangka as a raw material candidates CRM, and standard material JCRM-502 made in Japan.

\section{Instrumentation}

A set of tools XRF spectrometers, scales, sample containers, ball mill, a sieve size of 200 mesh, oven, mortar and pestle.

\section{Procedure}

Procurement of zirconium minerals as raw material for the synthesis of zirconium minerals CRM candidates, namely zirconium minerals from Kalimantan and Bangka (each weighing $10 \mathrm{~kg}$ ). The composition of zircon mineral from the raw materials was tested by XRF Spectrometry methods. Each raw materials mineral zircon from Kalimantan and Bangka (weighing $10 \mathrm{~kg}$ ) were dried at a $90^{\circ} \mathrm{C}$ for $2 \times 6 \mathrm{~h}$ in a closed room. Raw materials crushed with a ball mill 
until a particle size of 200 mesh pass, long grinding and sieving for $10 \times 6 \mathrm{~h}$. The raw material has been chopped passes 200 mesh homogenized in a homogenizer for $3 \times$ $6 \mathrm{~h}$. A homogenous powder of raw materials zircon mineral CRM candidates was obtained from the homogenizer which passes 200 mesh size as much as 2 $\mathrm{kg}$. The water content of the zircon mineral CRM candidates were tested by gravimetric method. Test of homogeneity zircon mineral CRM candidates was carried out with statistical methods.

\section{The homogenization test [13]}

Ten sub samples are randomly taken. Specified types of analytes represent the macro elements and micro elements for each type of analyte, to 10 subsamples were analyzed in the same laboratory, by the same analyst, using the same equipment and the same day. The analysis was performed in duplicate. follows:

Data analysis results statistically calculated as

Calculated on average test results siplo and duplo $\left(\mathrm{X}_{\mathrm{t}}\right)$ with the formula:

$\mathrm{X}_{\mathrm{t}}=\left(\mathrm{X}_{\mathrm{t}, 1}+\mathrm{X}_{\mathrm{t}, 2}\right) / 2$

where $X_{t, 1}$ is the result of the first test and $X_{t, 2}$ is the second test result

Calculated absolute differences (Wt) of the proceeds from the results siplo and duplo by the formula: $\mathrm{Wt}=\left|\mathrm{X}_{\mathrm{t}, 1}-\mathrm{X}_{\mathrm{t}, 2}\right|$

Calculated on average general (average) or coded $\mathrm{Xr}$ by the formula:

$\mathrm{Xr}=\sum \mathrm{Xt} / \mathrm{g}$

where $g$ is the number of subsamples that are used

Calculated standard deviation from the average subsample $\left(S_{x}\right)$ by the formula:

$\mathrm{S}_{\mathrm{X}}=\sqrt{\sum\left(\mathrm{X}_{\mathrm{t}, .}-\mathrm{X}_{\mathrm{r} . . .}\right)^{2} /(\mathrm{g}-1)}$

Calculated samples within the standard deviation $\left(S_{w}\right)$ with the formula:

$$
\mathrm{S}_{\mathrm{w}}=\sqrt{\sum \mathrm{w}_{\mathrm{t}}^{2} /(2 \mathrm{~g})}
$$

Calculated standard deviation between samples $\left(\mathrm{S}_{\mathrm{s}}\right)$ with formula:

$$
s_{s}=\sqrt{s_{s}^{2}-\left(s_{w}^{2} / s\right)}
$$

The sample is said to be homogeneous if $\mathrm{Ss} \leq 0.3$ $\sigma$, where $\sigma$ : standard deviation for proficiency assessment (SDPA), $\sigma$ can be established through CV Horwitz.

$\mathrm{CV}_{\text {Horwitz }}=2^{(1-0.5 \log \mathrm{C})}$

\section{The stability test [14]}

After storage for a certain time (3-6 months) performed the analysis again in duplicate. Test of stability carried out in the same laboratory with the implementation of the homogeneity test. Methods of stability testing were conducted using the same analysis with the same analyte compound according to assay analytes in homogeneity test (concentrations of $\mathrm{ZrO}_{2}$ and $\mathrm{HfO}_{2}$ with XRF spectrometry method). Selected a random subsample $g$ packaging, where $g \geq$ 3 . From the packaging $g$ subsample is selected, each package subsamples divided by 2 for purposes of duplo analysis. Each subsample was weighed $0.5 \mathrm{~g}$ then analyzed by XRF. The concentrations of $\mathrm{ZrO}_{2}$ and $\mathrm{HfO}_{2}$ were then determined from the XRF result. The concentration of $\mathrm{ZrO}_{2}$ at the stabilization test is the average concentration of the first (1) and second (2) measurements. The calculated average difference test results obtained in homogeneity $(\mathrm{Xr})$ by an average of the results obtained in the stability tests $(Y r)$. The sample is said to be stable if $|\mathrm{Xr}-\mathrm{Yr}| \leq 0.3 \sigma$.

The zircon mineral CRM candidates were distributed to 9 accredited testing laboratory for the analysis of elements and levels of uncertainty, namely: (1) Laboratory of Geological Survey Center, Bandung; (2) Laboratory of tekMIRA Center, Bandung; (3) Laboratory of PTNBR-BATAN, Bandung; (4) Laboratory of PT. Sucofindo, Surabaya; (5) Laboratory of PTBIN-BATAN, Serpong; (6) Laboratory of PTBNBATAN, Serpong; (7) Laboratory of AAN, PSTABATAN, Yogyakarta; (8) Laboratory of XRF, PSTABATAN, Yogyakarta and (9) Laboratory of AAS, PSTABATAN, Yogyakarta.

The standardization of CRM mineral zircon candidates was tested by comparing with JCRM- 502 standard materials and testing the composition of the oxide content in CRM mineral zircon candidates. In general, the composition of the compound content in the CRM material is often expressed in its oxidation concentration. The contents of oxides from various laboratories were evaluated with statistical methods.

\section{Certification oxides contents in CRM zircon mineral candidate}

For certification, candidate reference materials were distributed to 9 test laboratories for analysis. The composition of oxides content from various laboratories was calculated by statistical methods.

The calculation of the average grade oxide $(\bar{X})$ used the eq. 8.

$$
\begin{aligned}
& \bar{X}=\sum W_{i X i} \\
& W_{i}=\frac{W^{\prime}}{\sum_{i=1}^{p} W_{i}} \\
& W^{\prime}=\frac{1}{\mu^{2}}
\end{aligned}
$$

Calculation of uncertainty $(\mu)$ is used eq. 11 : 
$\mu(\bar{x})=\sqrt{\sum \mathrm{W}_{\mathrm{i}}^{2}} \mu_{\mathrm{xi}}^{2}$

where $\bar{X}$ : means of oxide contents, $X i$ is oxide content data from each Laboratory, $W$ is weight oxide, and $\mu$ is the uncertainty of oxide measurement.

\section{RESULT AND DISCUSSION}

The composition of Kalimantan zircon mineral raw materials was analyzed by XRF spectrometry methods, and the result is presented in Table 1.

In general, zircon mineral has the chemical formula of $\mathrm{ZrSiO}_{4}$ (Zirconium silicate). The major component of Zircon mineral from Kalimantan and Bangka are $\mathrm{SiO}_{2}$ and $\mathrm{ZrO}_{2}$. Based on Table 1, zircon mineral from Kalimantan (Tumbang Titi) and Bangka contain a lot of $\mathrm{Al}_{2} \mathrm{O}_{3}, \mathrm{Fe}_{2} \mathrm{O}_{3}, \mathrm{SiO}_{2}, \mathrm{TiO}_{2}$, and $\mathrm{ZrO}_{2}$. In addition to this oxides, in the zircon mineral from Bangka also contain rare earth metal oxide, i.e., $\mathrm{CeO}_{2}, \mathrm{La}_{2} \mathrm{O}_{3}, \mathrm{Nd}_{2} \mathrm{O}_{3}$, $\mathrm{Pr}_{6} \mathrm{O}_{11}, \mathrm{Sm}_{2} \mathrm{O}_{3}$, and $\mathrm{Y}_{2} \mathrm{O}_{3}$. For the certification process selected major, minor and some trace elements $(U$, Th).

\section{Water Content Test in Zircon Mineral CRM Candidate}

The water content in the mineral Zircon CRM candidates from Kalimantan and Bangka are presented in Table 2 and Table 3.

According to data of water content in Table 2 and Table 3, the data obtained for water content are $0.00 \%$. It means that the zircon mineral powder CRM candidate from Kalimantan and Bangka are dry and have been qualified as CRM, i.e., the water content less than $1 \%$. So it could be done for the homogeneity and stability testing.

Table 1. The content of the zircon mineral oxide from Kalimantan (Tumbang Titi) and Bangka by XRF spectrometry method

\begin{tabular}{rlcc}
\hline No & Oxide & ZM-Kalimantan (\%) & ZM-Bangka (\%) \\
\hline 1 & $\mathrm{Al}_{2} \mathrm{O}_{3}$ & 1.40 & 3.40 \\
2 & $\mathrm{CeO}_{2}$ & - & 4.40 \\
3 & $\mathrm{Cr}_{2} \mathrm{O}_{3}$ & 0.25 & - \\
4 & $\mathrm{Fe}_{2} \mathrm{O}_{3}$ & 5.85 & 2.19 \\
5 & $\mathrm{HfO}_{2}$ & 0.60 & 0.66 \\
6 & $\mathrm{La}_{2} \mathrm{O}_{3}$ & - & 2.15 \\
7 & $\mathrm{MnO}_{2}$ & 0.46 & - \\
8 & $\mathrm{Na}_{2} \mathrm{O}$ & 0.59 & - \\
9 & $\mathrm{Nd}_{2} \mathrm{O}_{3}$ & - & 1.53 \\
10 & $\mathrm{P}_{2} \mathrm{O}_{5}$ & - & 2.9 \\
11 & $\mathrm{Pr}_{6} \mathrm{O}_{11}$ & - & 0.33 \\
12 & $\mathrm{SiO}_{2}$ & 25.06 & 35.46 \\
13 & $\mathrm{SO}_{3}$ & - & 1.11 \\
14 & $\mathrm{Sm}_{2} \mathrm{O}_{3}$ & - & 0.14 \\
15 & $\mathrm{SnO}_{2}$ & - & 9.83 \\
16 & $\mathrm{TiO}_{2}$ & 2.40 & 2.88 \\
17 & $\mathrm{ThO}_{2}$ & 0.07 & 1.15 \\
18 & $\mathrm{U}_{3} \mathrm{O}_{8}$ & 0.04 & 0.17 \\
19 & $\mathrm{Y}_{2} \mathrm{O}_{3}$ & 0.21 & 0.41 \\
20 & $\mathrm{ZrO}_{2}$ & 40.49 & 27.55 \\
\hline
\end{tabular}

Table 2. Water content zircon mineral CRM candidates from Kalimantan

\begin{tabular}{cccc}
\hline No. & Zircon mineral from Kalimantan & Water content $(\%)$ & Average $(\%)$ \\
\hline 1 & MZK-1 & 0.00 & \\
2 & MZK-2 & 0.00 & \\
3 & MZK-3 & 0.00 & 0.00 \\
4 & MZK-4 & 0.00 & \\
5 & MZK-5 & 0.00 & \\
\hline
\end{tabular}

Table 3. Water content zircon mineral CRM candidates from Bangka

\begin{tabular}{cccc}
\hline No. & Zircon mineral from Bangka & Water content $(\%)$ & Average $(\%)$ \\
\hline 1 & MZB-1 & 0.00 & \\
2 & MZB-2 & 0.00 & \\
3 & MZB-3 & 0.00 & 0.00 \\
4 & MZB-4 & 0.00 & \\
5 & MZB-5 & 0.00 & \\
\hline
\end{tabular}




\section{Homogeneity Test of Zircon Mineral CRM Candidates}

\section{Homogeneity test of zircon mineral CRM candidates from Kalimantan}

To test the homogeneity of Zircon CRM candidates samples from Kalimantan can be seen in Supplement 1 (S-1) and Supplement 2 (S-2). As we know that the homogeneous sample can be found if the $S_{s} \leq 0.3 \sigma$, where $\sigma$ for the $\mathrm{ZrO}_{2}$ test can be calculated by eq. 7 .

$\mathrm{C}$ is $\mathrm{ZrO}_{2}$ concentration measured of $39.5681 \%$ or 0.3957. Therefore $\mathrm{CV}_{\text {Horwitz }}$ is 1.7395 , and $0.3 \mathrm{\sigma}$ is 0.5218 . The results of the test data homogenization using measured concentration of $\mathrm{ZrO}_{2}$, are shown in S-1 $\left(\mathrm{S}_{\mathrm{s}}=0.0018\right)$ so that CRM candidates are already homogeneous, because of $S_{s}$ value lower than $0.3 \sigma$ $(0.0018<0.5218)$.

The $\sigma$ for the $\mathrm{HfO}_{2}$ test can also be calculated by eq. 7. $\mathrm{C}$ is a measured concentration of $\mathrm{HfO}_{2}$ of $0.6484 \%$ or 0.006484 obtaining the value of $\mathrm{CV}_{\text {Horwitz }}$ of 4.2695 , and $0.3 \sigma$ is 1.2809. Evaluation of the test data homogenization using measured concentration of $\mathrm{HfO}_{2}$ (S-2) resulted of $S_{s}$ of $9.6567 \times 10^{-09}$, indicated that CRM candidates are already homogeneous because $S_{s}$ value is lower than $0.3 \sigma$ value $\left(9.6567 \times 10^{-09}<1.2809\right)$.

\section{Homogeneity test of zircon mineral CRM candidates from Bangka}

In the same way, the homogeneity test for samples of Zircon CRM candidates from Bangka was also conducted. Data acquisition for the homogeneity test of Zircon CRM candidate samples from Bangka is presented in S-3 and S-4.

From S-3, it is found that $\mathrm{C}$, the measured concentration of $\mathrm{ZrO}_{2}=29.2354 \%$ or 0.2923 . Therefore $\mathrm{CV}_{\text {Horwitz }}$ is 1.6620 , then $0.3 \sigma$ value is 0.4986 . The results of the test data homogenization using measured

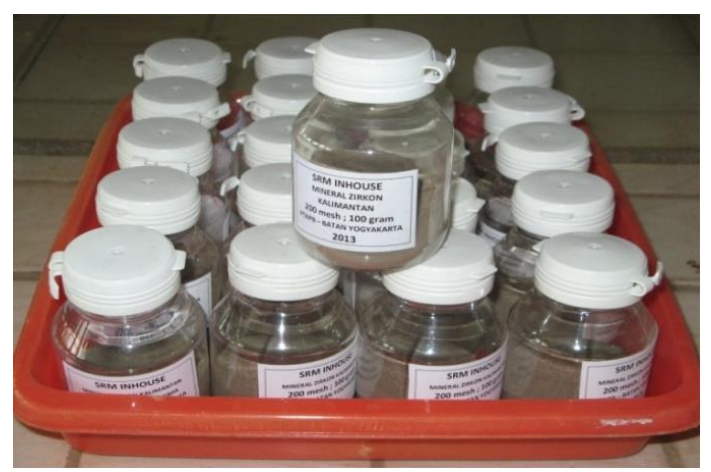

Fig 2. The powder of standard reference materials (inhouse) zirconium minerals from Kalimantan passes 200 mesh, number of 40 bottles, packs of $100 \mathrm{~g}$ concentration of $\mathrm{ZrO}_{2}$, are shown in S-3. The result obtained $S_{s}$ value of 0.00049 which is lower than $0.3 \sigma$ $(0.00049<0.4986)$. It indicated that CRM candidates are already homogeneous.

While from S-4, the measured concentration of $\mathrm{CeO}_{2}$ is $4.4473 \%$ or 0.0445 , resulting in the $\mathrm{CV}_{\text {Horwitz }}$ value of 2.0807 and $0.3 \sigma$ of 0.6242 . Evaluation of the test data homogenization using measured concentration of $\mathrm{CeO}_{2}$, (S-4) resulted in $\mathrm{S}_{\mathrm{s}}$ value of $1.48 \times 10^{-5}$ which indicated that CRM candidates are already homogeneous because the $S_{s}$ value is lower than $0.3 \sigma$ value $\left(1.48 \times 10^{-5}<0.6242\right)$.

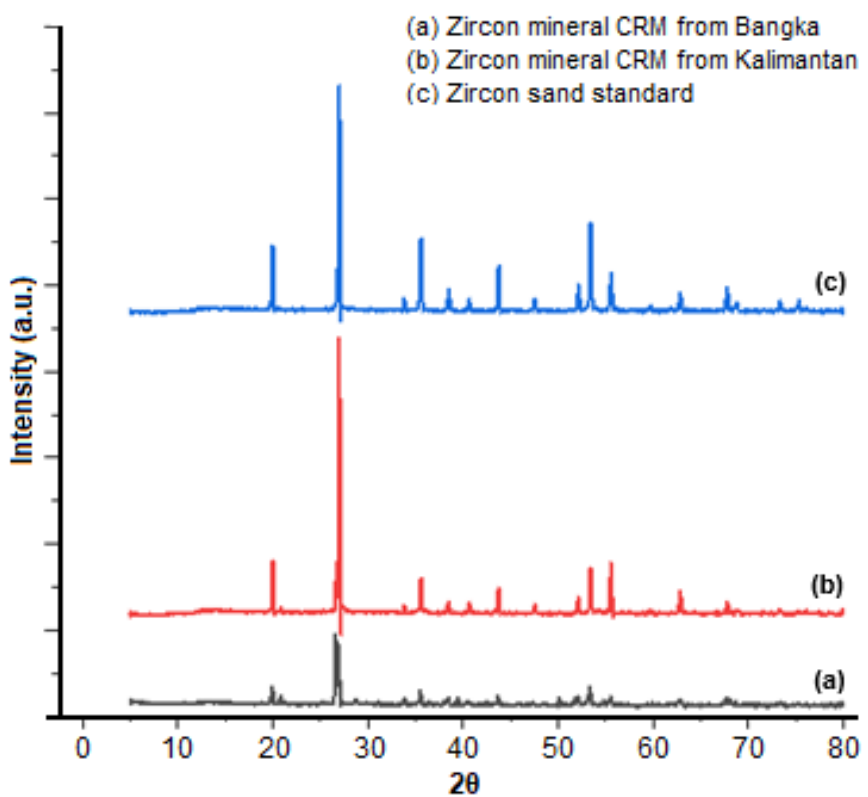

Fig 1. XRD spectra of CRM candidates sample mineral zircon from Bangka (a), Kalimantan (b) and zircon sand standard (c)

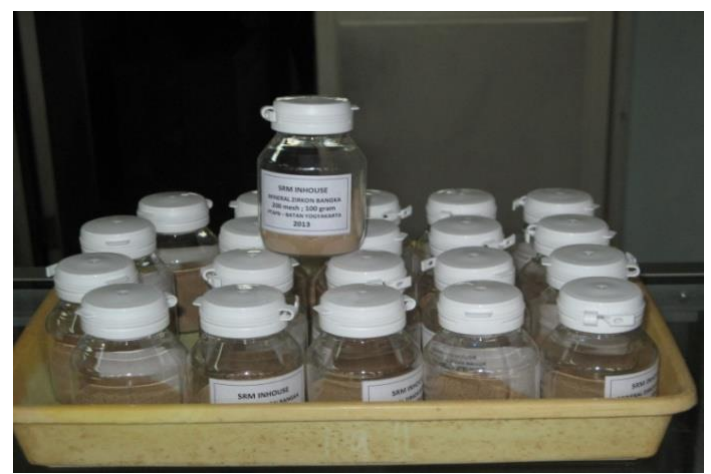

Fig 3. The powder of standard reference materials (inhouse) zirconium minerals from Bangka passes 200 mesh, number of 40 bottles, packs of $100 \mathrm{~g}$ 


\section{Stability Test of Zircon Mineral CRM Candidates}

\section{Stability test of zircon mineral CRM candidates from Kalimantan}

Data acquisition for the stability test of Zircon CRM candidate samples from Kalimantan is presented in S-5 and S-6. The sample acceptance criteria declared stable, if $|\mathrm{Xr}-\mathrm{Yr}| \leq 0.3 \sigma$. Homogeneity test data concentrations of $\mathrm{ZrO}_{2}$ (in S-1) obtained $\mathrm{Xr}$ value of 39.568, and the stability test data (S-5) resulted in $\mathrm{Yr}$ value of 39.247 , then the $|\mathrm{Xr}-\mathrm{Yr}|$ value is 0.3210 . Since the value of $0.3 \sigma$ is 0.5218 , the sample declared stable because it fulfills the criteria of $|\mathrm{Xr}-\mathrm{Yr}| \leq 0.3 \sigma$ i.e. 0.3210 $<0.5218$.

Meanwhile from the homogeneity test data of $\mathrm{HfO}_{2}$ concentrations (S-2) obtained Xr of 0.6585 and stability test data (S-6) obtained $\mathrm{Yr}$ is 0.6520 making the value of $|\mathrm{Xr}-\mathrm{Yr}|$ is 0.0065 . Since the value of $0.3 \sigma$ is 0.2817 , the sample is declared stable because it adequate the criteria of $|\mathrm{Xr}-\mathrm{Yr}| \leq 0.3 \sigma$, i.e., $0.0065<0.2817$. So based on the stabilization test of the data in S-5 and S-6, the condition of zircon mineral CRM candidate samples from Kalimantan is stable.

\section{Stability test of zircon mineral CRM candidates from Bangka}

The test data homogeneity concentrations of $\mathrm{ZrO}_{2}$ obtained $\mathrm{Xr}$ value of 29.2354 and stability test data (S-7) obtained $\mathrm{Yr}$ value of 28.8370 so that $|\mathrm{Xr}-\mathrm{Yr}|$ value is 0.3984 . The sample is declared stable because it meets the criteria $|\mathrm{Xr}-\mathrm{Yr}| \leq 0.3 \sigma$, i.e., $0.3984<0.4986$. While based on homogeneity test data of $\mathrm{CeO}_{2}$ concentrations (S-4) was obtained $\mathrm{Xr}$ of 4.4473 and stability test data
(S-8) obtained $\mathrm{Yr}$ of 4.3680 and then $|\mathrm{Xr}-\mathrm{Yr}|$ value is 0.0793 , and the value of $0.3 \sigma$ is 0.6242 . So that the sample declared stable because it meets the criteria $|\mathrm{Xr}-\mathrm{Yr}| \leq 0.3 \sigma$, i.e., $0.0793<0.6242$. So based on the stabilization test of the data in S-7 and S-8, the condition of zircon mineral CRM candidate samples from Bangka is stable.

\section{Standardization Test/Characterization of Zircon Mineral CRM Candidate}

Standardization/characterization of zircon mineral CRM candidate sample was performed using XRD method. The standardization test/characterization data of the mineral zircon CRM candidates are presented in Fig. 1.

The XRD spectra major compound between the sample and the standards are the same, namely zircon with a chemical formula of $\mathrm{ZrSiO}_{4}$. The standard contains very little mineral moissanite $(\mathrm{SiC})$, while the zircon mineral CRM candidate from Kalimantan contains little clay microcline $\left(\mathrm{KAl} \mathrm{Si}_{3} \mathrm{O}_{8}\right)$ and the zircon mineral CRM candidate from Bangka contains little rickardite $\left(\mathrm{Cu}_{4} \mathrm{Te}_{3}\right)$.

In Fig. 1(b), chemical compounds in the zircon mineral in-house CRM candidate from Kalimantan were zircon $\left(\mathrm{ZrSiO}_{4}\right)$, silicon oxide $\left(\mathrm{SiO}_{2}\right)$ and microcline $\left(\mathrm{KAISi}_{3} \mathrm{O}_{8}\right)$. Whereas in Fig. 1(a) chemical compounds in the zircon mineral in-house CRM candidate from Bangka were zircon $\left(\mathrm{ZrSiO}_{4}\right)$, low quartz $\left(\mathrm{SiO}_{2}\right)$ and rickardite $\left(\mathrm{Cu}_{4} \mathrm{Te}_{3}\right)$. Chemical compounds in zircon sand standard JCRM-502 (see Fig. 1(c)) were zircon $\left(\mathrm{ZrSiO}_{4}\right)$, and moissanite $(\mathrm{SiC})$.

Table 4. Certificate oxide concentrations in zircon minerals CRM in-house from Kalimantan and Bangka

\begin{tabular}{cccc}
\hline \multirow{2}{*}{ No } & \multirow{2}{*}{ Composition } & \multicolumn{2}{c}{ Concentration (\%) } \\
\cline { 2 - 4 } & & CRM MZ-Kalimantan & CRM MZ-Bangka \\
\hline 1 & $\mathrm{ZrO}_{2}$ & $39.320 \pm 0.120$ & $28.377 \pm 0.065$ \\
2 & $\mathrm{HfO}_{2}$ & $0,607 \pm 0.016$ & $0.667 \pm 0.011$ \\
3 & $\mathrm{SiO}_{2}$ & $23.416 \pm 0.062$ & $34.754 \pm 0.086$ \\
4 & $\mathrm{Fe}_{2} \mathrm{O}_{3}$ & $6.907 \pm 0.033$ & $2.315 \pm 0.018$ \\
5 & $\mathrm{TiO}_{2}$ & $23.907 \pm 0.062$ & $2.877 \pm 0.019$ \\
6 & $\mathrm{Al}_{2} \mathrm{O}_{3}$ & $1.376 \pm 0.018$ & $3.573 \pm 0.008$ \\
7 & $\mathrm{SnO}_{2}$ & - & $9.833 \pm 0.083$ \\
8 & $\mathrm{P}_{2} \mathrm{O}_{5}$ & - & $2.992 \pm 0.010$ \\
9 & $\mathrm{U}_{3} \mathrm{O}_{8}$ & $0.047 \pm 0.001$ & $0.176 \pm 0.003$ \\
10 & $\mathrm{ThO}_{2}$ & $0.070 \pm 0.010$ & $1.150 \pm 0.005$ \\
11 & $\mathrm{Y}_{2} \mathrm{O}_{3}$ & $0.214 \pm 0.006$ & $0.419 \pm 0.015$ \\
12 & $\mathrm{Sm}_{2} \mathrm{O}_{3}$ & - & $0.143 \pm 0.006$ \\
13 & $\mathrm{Pr}_{6} \mathrm{O}_{11}$ & - & $0.338 \pm 0.012$ \\
14 & $\mathrm{CeO}_{2}$ & - & $4.400 \pm 0.071$ \\
15 & $\mathrm{La}_{2} \mathrm{O}_{3}$ & - & $2.151 \pm 0.006$ \\
16 & $\mathrm{Nd}_{2} \mathrm{O}_{3}$ & - & $1.535 \pm 0.029$ \\
17 & $\mathrm{SO}_{3}$ & - & - \\
18 & $\mathrm{Na}_{2} \mathrm{O}$ & $0.596 \pm 0.021$ & - \\
19 & $\mathrm{MnO}_{2}$ & $0.461 \pm 0.003$ & - \\
20 & $\mathrm{Cr}_{2} \mathrm{O}_{3}$ & $0.249 \pm 0.005$ & \\
\hline
\end{tabular}




\section{Certifications [16]}

For certification zircon mineral CRM candidates used the eq. 9, meanwhile for calculation of the average oxide concentration ( $\left.X_{\text {average }}\right)$ used the eq. 8 and for calculation of uncertainty $(\mu)$ used the eq. 11.

In-house CRM Zircon Mineral candidate samples from both Kalimantan and Bangka were certified through a comparative test of 9 accredited laboratories by KAN (National Accreditation Committee). Obtained data of the comparative test results from 9 laboratories as listed in S-9 to S-12 for a sample of CRM mineral zircon candidate from Kalimantan and S-13 to S-14 for a sample of CRM mineral zircon candidate from Bangka. For the certification calculations, the other oxide concentrations can be carried out in the same

Table 5. The composition of zircon mineral CRM from Kalimantan, Bangka and standard JCRM R 502 from Japan

\begin{tabular}{|c|c|c|c|c|}
\hline \multirow{2}{*}{ No } & \multirow{2}{*}{ Composition } & \multicolumn{3}{|c|}{ Concentration (\%) } \\
\hline & & CRM MZ-Kalimantan & CRM MZ-Bangka & JCRM R 502-Japan \\
\hline 1 & $\mathrm{ZrO}_{2}+\mathrm{HfO}_{2}$ & - & - & $60.40 \pm 0.070$ \\
\hline 2 & $\mathrm{ZrO}_{2}$ & $39.320 \pm 0.120$ & $28.377 \pm 0.065$ & - \\
\hline 3 & $\mathrm{HfO}_{2}$ & $0,607 \pm 0.016$ & $0.667 \pm 0.011$ & - \\
\hline 4 & $\mathrm{SiO}_{2}$ & $23.416 \pm 0.062$ & $34.754 \pm 0.086$ & $32.80 \pm 0.200$ \\
\hline 5 & $\mathrm{Fe}_{2} \mathrm{O}_{3}$ & $6.907 \pm 0.033$ & $2.315 \pm 0.018$ & $0.10 \pm 0.002$ \\
\hline 6 & $\mathrm{TiO}_{2}$ & $23.907 \pm 0.062$ & $2.877 \pm 0.019$ & $0.24 \pm 0.009$ \\
\hline 7 & $\mathrm{Al}_{2} \mathrm{O}_{3}$ & $1.376 \pm 0.018$ & $3.573 \pm 0.008$ & $5.87 \pm 0.030$ \\
\hline 8 & $\mathrm{SnO}_{2}$ & - & $9.833 \pm 0.083$ & - \\
\hline 9 & $\mathrm{P}_{2} \mathrm{O}_{5}$ & - & $2.992 \pm 0.010$ & - \\
\hline 10 & $\mathrm{U}_{3} \mathrm{O}_{8}$ & $0.047 \pm 0.001$ & $0.176 \pm 0.003$ & - \\
\hline 11 & $\mathrm{ThO}_{2}$ & $0.070 \pm 0.010$ & $1.150 \pm 0.005$ & - \\
\hline 12 & $\mathrm{Y}_{2} \mathrm{O}_{3}$ & $0.214 \pm 0.006$ & $0.419 \pm 0.015$ & - \\
\hline 13 & $\mathrm{Sm}_{2} \mathrm{O}_{3}$ & - & $0.143 \pm 0.006$ & - \\
\hline 14 & $\mathrm{Pr}_{6} \mathrm{O}_{11}$ & - & $0.338 \pm 0.012$ & - \\
\hline 15 & $\mathrm{CeO}_{2}$ & - & $4.400 \pm 0.071$ & - \\
\hline 16 & $\mathrm{La}_{2} \mathrm{O}_{3}$ & - & $2.151 \pm 0.006$ & - \\
\hline 17 & $\mathrm{Nd}_{2} \mathrm{O}_{3}$ & - & $1.535 \pm 0.029$ & - \\
\hline 18 & $\mathrm{SO}_{3}$ & - & $1.115 \pm 0.035$ & - \\
\hline 19 & $\mathrm{Na}_{2} \mathrm{O}$ & $0.596 \pm 0.021$ & - & - \\
\hline 20 & $\mathrm{MnO}_{2}$ & $0.461 \pm 0.003$ & - & - \\
\hline 21 & $\mathrm{Cr}_{2} \mathrm{O}_{3}$ & $0.249 \pm 0.005$ & - & - \\
\hline
\end{tabular}

Table 6. Comparison of certification results between the mineral zircon (MZ) from Kalimantan and Bangka with the in-house zircon sand from Kalimantan, CRM (PZ) [15] and zircon sand CRM from Japan, JCRM R 502

\begin{tabular}{|c|c|c|c|c|c|}
\hline \multirow{2}{*}{ No } & \multirow{2}{*}{ Composition } & \multicolumn{4}{|c|}{ Concentration (\%) } \\
\hline & & CRM MZ-Kalimantan & CRM MZ-Bangka & CRM (PZ)-Kalimantan [15] & JCRM R 502-Japan \\
\hline 1 & $\mathrm{ZrO}_{2}+\mathrm{HfO}_{2}$ & - & - & - & $60.40 \pm 0.070$ \\
\hline 2 & $\mathrm{ZrO}_{2}$ & $39.320 \pm 0.120$ & $28.377 \pm 0.065$ & $52.889 \pm 0.070$ & $\begin{array}{l}- \\
-1000\end{array}$ \\
\hline 3 & $\mathrm{HfO}_{2}$ & $0,607 \pm 0.016$ & $0.667 \pm 0.011$ & $0.901 \pm 0.008$ & - \\
\hline 4 & $\mathrm{SiO}_{2}$ & $23.416 \pm 0.062$ & $34.754 \pm 0.086$ & $38.955 \pm 0.059$ & $32.80 \pm 0.200$ \\
\hline 5 & $\mathrm{Fe}_{2} \mathrm{O}_{3}$ & $6.907 \pm 0.033$ & $2.315 \pm 0.018$ & $0.746 \pm 0.004$ & $0.10 \pm 0.002$ \\
\hline 6 & $\mathrm{TiO}_{2}$ & $23.907 \pm 0.062$ & $2.877 \pm 0.019$ & $4.710 \pm 0.005$ & $0.24 \pm 0.009$ \\
\hline 7 & $\mathrm{Al}_{2} \mathrm{O}_{3}$ & $1.376 \pm 0.018$ & $3.573 \pm 0.008$ & $0.657 \pm 0.004$ & $5.87 \pm 0.030$ \\
\hline 8 & $\mathrm{SnO}_{2}$ & - & $9.833 \pm 0.083$ & - & - \\
\hline 9 & $\mathrm{P}_{2} \mathrm{O}_{5}$ & - & $2.992 \pm 0.010$ & - & - \\
\hline 10 & $\mathrm{U}_{3} \mathrm{O}_{8}$ & $0.047 \pm 0.001$ & $0.176 \pm 0.003$ & - & - \\
\hline 11 & $\mathrm{ThO}_{2}$ & $0.070 \pm 0.010$ & $1.150 \pm 0.005$ & - & - \\
\hline 12 & $\mathrm{Y}_{2} \mathrm{O}_{3}$ & $0.214 \pm 0.006$ & $0.419 \pm 0.015$ & - & - \\
\hline 13 & $\mathrm{Sm}_{2} \mathrm{O}_{3}$ & - & $0.143 \pm 0.006$ & - & - \\
\hline 14 & $\mathrm{Pr}_{6} \mathrm{O}_{11}$ & - & $0.338 \pm 0.012$ & - & - \\
\hline 15 & $\mathrm{CeO}_{2}$ & - & $4.400 \pm 0.071$ & - & - \\
\hline 16 & $\mathrm{La}_{2} \mathrm{O}_{3}$ & - & $2.151 \pm 0.006$ & - & - \\
\hline 17 & $\mathrm{Nd}_{2} \mathrm{O}_{3}$ & - & $1.535 \pm 0.029$ & - & - \\
\hline 18 & $\mathrm{SO}_{3}$ & - & $1.115 \pm 0.035$ & - & - \\
\hline 19 & $\mathrm{Na}_{2} \mathrm{O}$ & $0.596 \pm 0.021$ & - & - & - \\
\hline 20 & $\mathrm{MnO}_{2}$ & $0.461 \pm 0.003$ & - & - & - \\
\hline 21 & $\mathrm{Cr}_{2} \mathrm{O}_{3}$ & $0.249 \pm 0.005$ & - & $0.528 \pm 0.005$ & - \\
\hline
\end{tabular}


manner as in S-9 to S-15.

Table 4 shows the results of a complete certification of in-house CRM mineral zircon samples from Kalimantan and Bangka.

The results of the study were powder zircon mineral CRM in-house from Kalimantan (Tumbang Titi) which passes 200 mesh was then presented in Fig. 2, and zircon mineral CRM in-house from Bangka was presented in Fig. 3.

The in-house zircon mineral CRM from Kalimantan and Bangka certification results are not much different when compared with previous similar results, as Taftazani et al. [15] has already produced in-house zircon sand CRM from Kalimantan and by the Ceramics Society Japan which has produced JCRM zircon sand, also Britain which has made Standard Zircon BCS-RM No. 204a [17] and No. 388 [18] which produced by BAS (Bureau of Analyzed Samples LTD). It's just that when viewed from the macro element content such as $\mathrm{ZrO}_{2}$, $\mathrm{HfO}_{2}, \mathrm{SiO}_{2}, \mathrm{TiO}_{2}, \mathrm{Fe}_{2} \mathrm{O}_{3}$, and $\mathrm{Al}_{2} \mathrm{O}_{3}$, only the matrix contained in zircon minerals from Kalimantan and Bangka are somewhat different from zircon sands of Kalimantan and zircon sands of Japan, as well as zircon standards of Great Britain, which can be seen in Table 5,6 and 7 .

In general, zirconium minerals have the chemical formula of $\mathrm{ZrSiO}_{4}$ (Zirconium silicate). Although some zircon specimens contain a large number of elements, others comprise only zirconium, silicon and oxygen in proportions according to the formula. As seen in the zircon standard BCS-CRM No. 204a and No. 388, its chemical composition consists of $\mathrm{ZrO}_{2}, \mathrm{SiO}_{2}, \mathrm{Al}_{2} \mathrm{O}_{3}$, $\mathrm{TiO}_{2}, \mathrm{Fe}_{2} \mathrm{O}_{3}, \mathrm{HfO}_{2}$ and other elements in small quantities [17-18].

\section{CONCLUSION}

In-house zircon minerals CRM from Kalimantan and Bangka have been made. The oxide composition in the in-house zircon minerals from Kalimantan there are 12 oxides and in the in-house zircon mineral from Bangka there are 17 oxides. The content of minerals and chemical compounds in the in-house zircon mineral CRM from Kalimantan were Zircon $\left(\mathrm{ZrSiO}_{4}\right)$, silicon oxide $\left(\mathrm{SiO}_{2}\right)$, microcline $\left(\mathrm{KAISi}_{3} \mathrm{O}_{8}\right)$ and in the inhouse zircon mineral CRM from Bangka silicon oxide $\left(\mathrm{SiO}_{2}\right)$ and rickardite $\left(\mathrm{Cu}_{4} \mathrm{Te}_{3}\right)$. Obtained the method of

Table 7. The composition of zircon Mineral CRM from Kalimantan, Bangka, standard of BCS-RM No. 204a and Standard of BCS-RM No. 388 from BAS (Bureau Analyzed Samples LTD)

\begin{tabular}{|c|c|c|c|c|c|}
\hline \multirow[b]{2}{*}{ No } & \multirow[b]{2}{*}{ Composition } & \multicolumn{4}{|c|}{ Concentration (\%) } \\
\hline & & $\begin{array}{l}\text { CRM MZ- } \\
\text { Kalimantan }\end{array}$ & $\begin{array}{l}\text { CRM MZ- } \\
\text { Bangka }\end{array}$ & $\begin{array}{l}\text { Standard of BCS-RM } \\
\text { No. 204a Zircon [17] }\end{array}$ & $\begin{array}{c}\text { Standard of BCS-RM } \\
\text { No. } 388 \text { Zircon [18] }\end{array}$ \\
\hline 1 & $\mathrm{ZrO}_{2}+\mathrm{HfO}_{2}$ & - & - & $53.8 \pm 0.3$ & - \\
\hline 2 & $\mathrm{ZrO}_{2}$ & $39.320 \pm 0.120$ & $28.377 \pm 0.065$ & - & $66.2 \pm 0.1$ \\
\hline 3 & $\mathrm{HfO}_{2}$ & $0,607 \pm 0.016$ & $0.667 \pm 0.011$ & - & - \\
\hline 4 & $\mathrm{SiO}_{2}$ & $23.416 \pm 0.062$ & $34.754 \pm 0.086$ & $37.6 \pm 0.3$ & $32.7 \pm 0.1$ \\
\hline 5 & $\mathrm{Fe}_{2} \mathrm{O}_{3}$ & $6.907 \pm 0.033$ & $2.315 \pm 0.018$ & $0.18 \pm 0.01$ & $0.049 \pm 0.004$ \\
\hline 6 & $\mathrm{TiO}_{2}$ & $23.907 \pm 0.062$ & $2.877 \pm 0.019$ & $2.22 \pm 0.06$ & $0.232 \pm 0.006$ \\
\hline 7 & $\mathrm{Al}_{2} \mathrm{O}_{3}$ & $1.376 \pm 0.018$ & $3.573 \pm 0.008$ & $0.74 \pm 0.04$ & $0.291 \pm 0.009$ \\
\hline 8 & $\mathrm{SnO}_{2}$ & - & $9.833 \pm 0.083$ & $1.69 \pm 0.11$ & - \\
\hline 9 & $\mathrm{P}_{2} \mathrm{O}_{5}$ & - & $2.992 \pm 0.010$ & $0.74 \pm 0.02$ & $0.122 \pm 0.010$ \\
\hline 10 & $\mathrm{U}_{3} \mathrm{O}_{8}$ & $0.047 \pm 0.001$ & $0.176 \pm 0.003$ & 0.12 & $0.034 \pm 0.004$ \\
\hline 11 & $\mathrm{ThO}_{2}$ & $0.070 \pm 0.010$ & $1.150 \pm 0.005$ & 0.21 & $0.019 \pm 0.002$ \\
\hline 12 & $\mathrm{Y}_{2} \mathrm{O}_{3}$ & $0.214 \pm 0.006$ & $0.419 \pm 0.015$ & 0.28 & $0.136 \pm 0.009$ \\
\hline 13 & $\mathrm{Sm}_{2} \mathrm{O}_{3}$ & - & $0.143 \pm 0.006$ & 0.04 & - \\
\hline 14 & $\mathrm{Pr}_{6} \mathrm{O}_{11}$ & - & $0.338 \pm 0.012$ & 0.06 & - \\
\hline 15 & $\mathrm{CeO}_{2}$ & - & $4.400 \pm 0.071$ & 0.61 & - \\
\hline 16 & $\mathrm{La}_{2} \mathrm{O}_{3}$ & - & $2.151 \pm 0.006$ & 0.26 & - \\
\hline 17 & $\mathrm{Nd}_{2} \mathrm{O}_{3}$ & - & $1.535 \pm 0.029$ & 0.23 & - \\
\hline 18 & $\mathrm{SO}_{3}$ & - & $1.115 \pm 0.035$ & - & - \\
\hline 19 & $\mathrm{Na}_{2} \mathrm{O}$ & $0.596 \pm 0.021$ & 1.1010 .000 & $0.014 \pm 0.002$ & $<0.02$ \\
\hline 20 & $\mathrm{MnO}_{2}$ & $0.461 \pm 0.003$ & - & - & - \\
\hline 21 & $\mathrm{Cr}_{2} \mathrm{O}_{3}$ & $0.249 \pm 0.005$ & - & - & - \\
\hline 22 & $\mathrm{CaO}$ & - & - & $0.15 \pm 0.01$ & 0.04 \\
\hline 23 & $\mathrm{MgO}$ & - & - & $0.012 \pm 0.001$ & $<0.05$ \\
\hline 24 & $\mathrm{~K}_{2} \mathrm{O}$ & - & - & $0.017 \pm 0.02$ & $<0.03$ \\
\hline 25 & $\mathrm{Gd}_{2} \mathrm{O}_{3}$ & - & - & 0.03 & - \\
\hline 26 & $\mathrm{Sc}_{2} \mathrm{O}_{3}$ & - & - & 0.02 & - \\
\hline 27 & $\mathrm{Ta}_{2} \mathrm{O}_{5}$ & - & - & 0.02 & - \\
\hline 28 & LOI & - & - & $0.50 \pm 0.06$ & 0.20 \\
\hline
\end{tabular}


zircon mineral CRM synthesis includes the preparation of candidate materials, weighing, drying, grinding and sieving with homogeneity and stability testing updates. This in-house CRM of zircon minerals were traceable to certified zircon sand reference materials from Japan (JCRM R 502).

\section{ACKNOWLEDGEMENT}

On this occasion, the authors thank profusely to DIPA budget year 2013, Supriyanto, C., Mulyono, Sutanto, W.W, Rosidi, Suhardi, Sukirno, and Sukadi.

\section{REFERENCES}

[1] Purwastien, P., Judprasong, K., and Pinprapai, N., 2009, Development of rice reference material and its use for evaluation of analytical performance of food analysis laboratories, J. Food Compos. Anal., 22, 453-462.

[2] Guimarães, E.F., do Rego, E.C.P., Cunha, H.C.M., Rodrigues, J.M., and Figueroa-Villar, J.D., 2014, Certified reference material for traceability in environmental analysis: PAHs in toluene, J. Braz. Chem. Soc., 25 (2), 351-360.

[3] Quan, C., Yao, H., and Hou, C., 2013, Certification and uncertainty evaluation of flavonoids certified reference materials, J. Agric. Sci., 4 (9B), 89-96.

[4] McCarron, P., Reeves, K.L., Giddings, S.D., Beach, D.G., and Quilliam, M.A., 2016, Development of certified reference materials for diarrhetic shellfish poisoning toxins, part 2: Shellfish matrix materials, J. AOAC Int., 99 (5), 1163-1172.

[5] Nogueira, R., do Rego, E.C.P., Sousa, M.V.B., Wollinger, W., da Silva, T.E., Moreira, G.F., Barin, J.M., Laporta, L.V., Mesko, M.F., Bittencourt, C.F., Rodrigues, J.M., and da Cunha, V.S., 2011, Development studies of captopril certified reference material, Braz. J. Pharm. Sci., 47 (2), 339-350.

[6] Dai, X., Fang, X., Shao, M., Li, M., Huang, Z., Li, H., Jiang, Y., Song, D., and He, Y., 2011, Corrigendum to "certified reference materials (GBW09170 and 09171) of creatinine in human serum", $J$. Chromatogr. B, 879 (20), 1845.

[7] Magharbeh, M., Fayyad, M., and Bartarseh, M., 2012, Preparation of natural standard reference material (SRM) for El-lajjun oil shale/Jordan, Jordan J. Earth .Environ. Sci., 4 (2), 15-22.

[8] Rimmer, C.A., Putzbach, K., Sharpless, K.E., Sander, L.C., and Yen, J.H., 2012, Preparation and certification of standard reference material 3278 tocopherols in edible oils, J. Agric. Food Chem., 60 (27), 6794-6798

[9] Portugal, T.R., Parcon, M.R.V., and Udarbe, M.A., 2013, Proficiency test on total dietary fiber in wheat flour, Int. J. Chem. Eng. Appl., 4 (2), 82-87.

[10] Bebić, J.M., Gažević, L.S., and Bläul, C., 2016, Prolab software for data evaluation of interlaboratory studies, Int. J. Adv. Qual., 44 (3), 23-28.

[11] Ahadnejad, V., Valizadeh, M.V, Esmaeily D., and Bokani, S.J., 2008, Setting in-house XRF reference material for minerals; A case study: Botite minerals or malayer granitoid rocks (Western Iran), J. Appl. Sci., 8 (23), 4369-4375.

[12] Jedziniak, P., Szprengier-Juszkiewicz, T., and Olejnik, M., 2009, In-house reference materials: 5hydroxyflunixin and meloxicam in cow milkpreparation and evaluation, Anal. Chim. Acta, 637 91-2), 346-350.

[13] Ulrich, J.C., Sarkis, J.E.S., and Hortellani, M.A., 2015, Homogeneity study of candidate reference material in fish matrix, J. Phys. Conf. Ser., 575, 012040.

[14] Korpysa-Dzirba, W., Rola, J.G., and Osek, J., 2012. Homogeneity and stability of samples used for proficiency testing in enumeration of coagulase positive staphylococci, Bull Vet. Inst. Pulawy, 56 (4), 559-562.

[15] Taftazani, A., Prihatin, S., Sunanti, S.T., Suprianto, C., and Suratman, S., 2012, Preparation of certified reference materials (CRMs) zircon sand, $13^{\text {th }}$ International Symposium on Biological and Environmental Reference Materials (BERM 13), Vienna, Austria.

[16] ISO Guide 35, 1989, Certification of reference Materials - General and statistic principles.

[17] British Chemical Standard-Reference Material, 1991, Zircon, Analysis Report, BCS-RM No. 204a.

[18] British Chemical Standard-Reference Material, 2015, Zircon, Certificate of Analysis, BCS-RM No. 388. 